\title{
PHYTOPLANKTON COMPOSITION AND ECOLOGICAL TOLERANCE OF THE AUTOTROPHIC PICOPLANKTON IN ATANASOVSKO LAKE (BLACK SEA COASTAL LAGOON, BULGARIA)
}

\author{
Belkinova, D. ${ }^{1,2}$ - Teneva, I. $.^{*}-$ Basheva, D. ${ }^{1}-$ Neykov, N. ${ }^{3}-$ Moten, D. ${ }^{1}-$ Gecheva, G. ${ }^{1}$ \\ - Apostolova, E. ${ }^{1}-$ NAIMOV, S. ${ }^{1}$ \\ ${ }^{1}$ Plovdiv University "Paisii Hilendarski”, 24 Tsar Assen Str., Plovdiv 4000, Bulgaria \\ ${ }^{2}$ Institute of Biodiversity and Ecosystem Research, Bulgarian Academy of Sciences, 23 Acad. G. \\ Bonchev Str., Sofia 1113, Bulgaria \\ ${ }^{3}$ National Institute of Meteorology and Hydrology, Sofia, Bulgaria \\ ${ }^{*}$ Corresponding author \\ e-mail: teneva@uni-plovdiv.bg; phone: +359-32-261-514; fax: +359-32-261-566
}

(Received $31^{\text {st }}$ Oct 2020; accepted $21^{\text {st }}$ Dec 2020)

\begin{abstract}
Atanasovsko Lake is a coastal lagoon used for salt extraction for many years. Its salinity varies within a wide range (from 6.3 to $>72 \%$ ). Despite these extreme conditions, phytoplankton blooms are often observed. Therefore, our aim was to study the key abiotic drivers and ecological optimum of the picoplankton in a 5-year period (2013-2017). The taxonomic composition, long-term dynamics and abiotic drivers of the autotrophic picoplankton (APP) has been investigated in North Saltern of the coastal lagoon in Atanasovsko Lake. The APP species were identified by using a polyphasic approach based on molecular and phylogenetic analyses of $16 \mathrm{~S} / 18 \mathrm{~S}$ rDNA in combination with cytomorphological and ecological characterization. Picochlorum oklahomense (Trebouxiophyceae, Chlorophyta) and marine Synechococcus sp. (Synechococcales, Cyanobacteria) were the dominant genotypes within the APP. The relative biovolume of the APP to the total phytoplankton biovolume was strongly variable (from 36 to $99 \%$ ) as the salinity and temperature were found to be the main abiotic drivers of its dynamics. Salinity between $30-59 \%$ and mid-summer temperature above $24^{\circ} \mathrm{C}$ provide an ecological optimum for the APP development at a relative biovolume of $93 \%$. This is the first record of Picochlorum oklahomense/Synechococcus sp. assemblage within the APP composition of a European coastal lagoon.
\end{abstract}

Keywords: ecology, hypersaline lakes, Synechococcus, Picochlorum oklahomense, 16S/18S DNA

\section{Introduction}

Over the last decade, a number of studies have focused on the autotrophic picoplankton (APP) in saline inland waters of Europe (Felföldi et al., 2009; Somogyi et al., 2011, 2014; Keresztes et al., 2012; Paranhos et al., 2017). Unusually high abundance of APP with extraordinarily high picoplankton productivity was registered in soda lakes in the Carpathian Basin (Felföldi et al., 2009). The APP abundance in hypersaline lakes is higher than those in freshwater and marine environments with similar trophic conditions, and the contribution of the APP to the total phytoplankton community can reach up to $90-100 \%$ (Somogyi et al., 2014). The selective advantage of pico-sized primary producers in turbid waters is related to the more effective utilization of the light and nutrients (Agustí, 1991; Reynolds, 2006; Felföldi et al., 2009) and reducing grazing pressure (Paranhos et al., 2017). These results confirmed the assumption of Krienitz et al. (2012) that APP has a key position as a highly productive 
primary producer in saline environments and therefore, more attention should be paid to its distribution.

Saline waters also include coastal lagoons and salterns. Coastal lagoons are shallow brackish or marine water bodies separated from the ocean by a barrier island, spit, reef, or sand bank (Barnes, 1980; Kennish and Paerl, 2010; Kennish, 2015). They are formed on shallow banks and are only $12 \%$ of the coastal shorelines worldwide (Kennish, 2015). Most of them are situated along African coast (17.9\% from shoreline) and North America (17.6\%), and only 5.3\% are on European territory (Kennish, 2015). Lagoons are characterized with spatial and temporal natural variability, which is not typical for the other aquatic ecosystems (Barnes, 1980). This variability is represented as a strong ecological stress, which forms the community structure. Due to the rarity of these habitats and species that they sustain, coastal lagoons are of primary conservational importance.

Studies on the picophototrophic communities in coastal lagoons and salterns are scarce (Ayadi et al., 2004; Estrada et al., 2004; Elloumi et al., 2009; Schapira et al., 2010). The available results analyzed mainly the dynamics of APP abundance under the influence of abiotic and biotic drivers (Elloumi et al., 2009; Schapira et al., 2010). The reports about the taxonomic composition of APP are even rarer. By applying moleculargenetic methods, a new species Picocystis salinarum (Prasinophyceae) has been described from the San Francisco salterns, California, USA (Lewin et al., 2001). Annual domination of the green algae Picochlorum sp. and Picocystis sp. was recorded in a coastal lagoon in San Diego, California, USA (Wang et al., 2014).

The object of our study was Atanasovsko Lake, a coastal lagoon located on the Black Sea coast in Southeast Bulgaria. The major part of the lake was modified as salterns. Atanasovsko Lake includes a variety of habitats and it is located along the second largest migration route of birds from Europe to Africa, Via Pontica. Our aim was to study the key abiotic drivers and ecological optimum of the picoplankton towards abiotic drivers in a 5-year period.

This is the first study on the taxonomic composition and long-term dynamics of the abundance of APP in a European coastal lagoon.

\section{Materials and methods}

\section{Site description}

Atanasovsko Lake is a coastal lagoon separated from Black Sea via sand spit, about $1 \mathrm{~km}$ long (Fig. 1A,B). It is below the sea level (-1.5 $\mathrm{m}$ a.s.l.). The volume of the lake is 3.2 mil. $\mathrm{m}^{3}$, the average depth is $0.3 \mathrm{~m}$, and the surface is $10.9 \mathrm{~km}^{2}$ (Gecheva et al., 2017).

The lake has been used for salt production since 1906 and was separated by dykes on small basins for salt extraction. The key factor for the lake is the mechanism of salt production and sea-freshwater exchange (Hubenov et al., 2015). Freshwater supply is via atmospheric deposition (rainfall) and river waters (Azmaka and Vetrenska rivers). The inflow of seawater is achieved via sluice from April and continues with varying intensity throughout the summer until the autumn. Due to the decrease in rainfall and the continuous evaporation of water from the crystallization basins, salinity increases almost twice from spring to autumn every year (Ivanov et al., 1964), reaching extreme values in some years - up to 169\%o (Botev, 1997). 

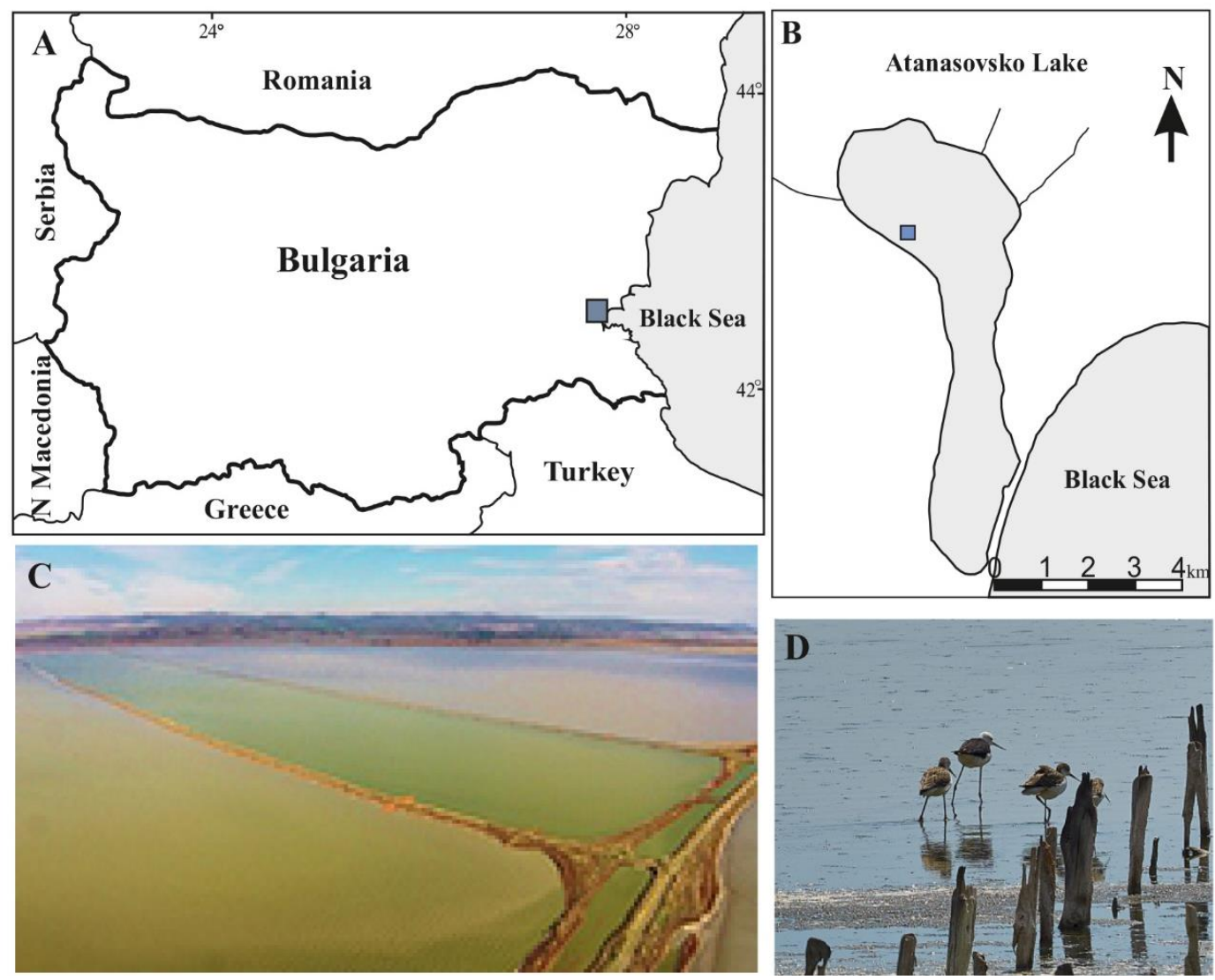

Figure 1. Atanasovsko Lake. A: Map of Bulgaria (the square shows the location of Atanasovsko

Lake); B: Map of Atanasovsko Lake (the square shows the location of the study pond North Saltern); C: Study pond North Saltern with an intensive bloom of APP; D: Habitat of APP, with a high abundance of waterfowl

Our study was focused on a small basin in the North Saltern (N 42 $34^{\prime} 16.4^{\prime \prime}$; E $27^{\circ} 28^{\prime} 04.4^{\prime \prime}$ ) for the period 2013-2017 (Fig. 1C). The pond is characterized by variable salinity and intensive blooms of picoplankton. Atanasovsko Lake is one of the most significant wetlands for conregations of waterfowl along the Bulgarian Black Sea coast (Fig. 1D).

\section{Sample techniques}

Water samples for physico-chemical analyzes were taken five times per each year (2013, 2014, 2015, 2016 and 2017) during the months March, June, July, September and October in the pond North Saltern. The parameters $\mathrm{pH}$, conductivity, temperature and dissolved oxygen/oxygen saturation were measured in situ with Multi 3410 SET B TetraCON 952-3 (WTW). Nutrients were analyzed by pHotoFlex STD (WTW)

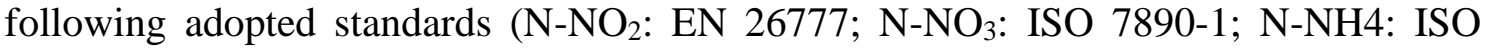
7150/1; P-PO4: EN ISO 6878). During the study period (2013-2017) twenty-five water samples were collected for physico-chemical analyzes. Chlorophyll- $a$ concentration was determined spectrophotometrically (M107 Visible Spectrophotometer, Spectronic Camspec Ltd., Leeds, UK) according to ISO 10260: 2002. North Saltern waters were classified as mixo- to hypersaline according to the Venice System (Anonymous, 1958). 
The phytoplankton sampling was performed three times per year (2013-2017) during the summer season from June to September. In 2015, phytoplankton samples were collected two times instead three times. Due to the shallow depth and lack of vertical salt gradient in the lake, samples were collected with a Meyer bottle from the subsurface layer and fixed in situ with formaldehyde (4\% final concentration). During the study period (2013-2017), 14 phytoplankton samples were analyzed.

\section{Isolation and cultivation of the APP species}

The APP species were isolated by streaking cells across agar plates (Andersen and Kawachi, 2005) from living natural samples in 2016 when were registered unusual highly-dense phytoplankton blooms. The strain PACC 8945 was isolated from a bloom sample in June $2016\left(\mathrm{~T}=27^{\circ} \mathrm{C} ; \mathrm{S}=30.3 \%\right)$ and cultured on liquid medium with seawater (Schlösser, 1982), modified by addition of $\mathrm{Na}_{2} \mathrm{CO}_{3}(\mathrm{pH}=8.5)$. The strain PACC 8946 was isolated from a bloom sample in July $2016\left(\mathrm{~T}=27.6^{\circ} \mathrm{C} ; \mathrm{S}=59 \%\right.$ ) and cultured on liquid medium with artificial seawater (Eddy, 1956). Algal cultures were maintained in a laboratotory at room temperature $\left(22^{\circ} \mathrm{C} \pm 2{ }^{\circ} \mathrm{C}\right)$ and a $15: 9$ hour light:dark cycle. Two unialgal strains (PACC 8945, PACC 8946) were deposited in Plovdiv Algal Culture Collection (PACC) of Plovdiv University in Bulgaria.

\section{Extraction of DNA, PCR amplification and sequencing of the prokaryotic species (16S DNA)}

Genomic DNA was extracted from the cultured cyanobacterial mass by the Proteinase-K extraction method. The concentration of the DNA and its purity was measured on a NanoDrop 2000 UV-Vis spectrophotometer (Thermo Fisher Scientific, Wilmington, DE, USA). The integrity of the extracted DNA was visualized on an agarose gel by ethidium bromide staining and UV transillumination (MiniBIS Pro gel documentation system, DNR Bio-Imaging Systems Ltd., Jerusalem, Israel). Isolated DNA was used to perform PCR amplification of 16S DNA. 16S DNA was amplified by using the primers 27F (5'-AGAGTTTGATCCTGGCTCAG-3') and 1492R (5'-CGGTTACCTTGTTACGACTT-3'). PCR reactions were conducted using PuReTaq ${ }^{\mathrm{TM}}$ Ready-To-Go ${ }^{\mathrm{TM}}$ PCR beads (GE Healthcare, Buckinghamshire, UK) where the final mixture contained $1.5 \mathrm{U}$ of Taq DNA polymerase, $10 \mathrm{mM}$ of Tris- $\mathrm{HCl} \mathrm{pH} 9$, $50 \mathrm{mM}$ of KCl, $1.5 \mathrm{mM}$ of $\mathrm{MgCl}_{2}, 200 \mu \mathrm{M}$ of each dNTP, 5 pmol of each of the two primers, $100 \mathrm{ng}$ of genomic DNA, and water to a final volume of $25 \mu \mathrm{l}$. Amplification was done in a TC-412 thermal cycler (Techne, Cambridge Ltd., UK) using the following program: initial denaturation for 5 minutes at $94^{\circ} \mathrm{C}$, followed by 30 cycles of 60 seconds at $95^{\circ} \mathrm{C}, 60$ seconds at $53^{\circ} \mathrm{C}, 2$ minutes at $72^{\circ} \mathrm{C}$, and final elongation step of 10 minutes at $72^{\circ} \mathrm{C}$. All PCR products were analyzed by electrophoresis in a $1.5 \%$ agarose gel in Tris-acetate-EDTA (TAE) buffer with GeneRuler ${ }^{\mathrm{TM}} 100$ bp DNA Ladder Plus as a size marker (Fermentas Life Sciences), stained with ethidium bromide, and visualized under UV trans-illumination. After visualizing the bands under UV light, amplified product was cut out of the gel and purified using a DNA extraction kit (Fermentas Life Sciences).

The purified product of 16S DNA was sent for direct sequencing (Eurofins MWG Operon, Ebersberg, Germany). Sequencing was done employing the same primers used for PCR amplification. The nucleotide sequence of 16S rRNA gene obtained from DNA sequencing was compared with other cyanobacterial sequences from the NCBI database using BLAST (http://www.ncbi.nlm.nih.gov/BLAST). The sequence was deposited in 
the GenBank (Nacional Center for Biotechnology Information, NCBI) under accession number MN061337.

\section{Extraction of DNA, PCR amplification and sequencing of the eukaryotic species (18S DNA)}

The dominant eukaryotic species were cultured under aseptic conditions and genomic DNA was isolated. Five milliliters of microalgae culture were harvested by centrifugation at $14000 \mathrm{RPM}$ on Eppendorf 5424R centrifuge and used for DNA preparation. Genomic DNA from the strain PACC 8946 was isolated using QIAamp DNA Mini Kit (QIAGEN) according to the manufacturer requirements. The DNA concentration and quality was determined spectrophotometrically at a wavelength of $260 \mathrm{~nm}$ using Epoch microtiter plate reader and T3 plate protocol. Ribosomal DNA encoding genes were amplified according Yamamoto et al. (2003). Briefly, the reaction was carried out in a $50 \mu \mathrm{l}$ reaction mixture that contained $1 \mathrm{x}$ reaction buffer, $200 \mu \mathrm{M}$ dNTPs, $0.2 \mu \mathrm{M}$ 5'-PCR 1-primer (ACCTGGTTGATCCTGCCAGT), $0.2 \mu \mathrm{M}$ 3'-PCR 3-primer (CCTTCYGCAGGTTCACCTAC), $100 \mathrm{ng}$ microalgal genomic DNA, and 1 unit of Q5 High Fidelity DNA polymerase (New England Biolabs). The samples were placed in a thermocycler and subjected to 30 PCR cycles of denaturation at $95^{\circ} \mathrm{C}$ for $60 \mathrm{~s}$, annealing at $66^{\circ} \mathrm{C}$ for $60 \mathrm{~s}$, and extension at $72^{\circ} \mathrm{C}$ for $60 \mathrm{~s}$. There was a final extension step at $72^{\circ} \mathrm{C}$ for $10 \mathrm{~min}$. PCR amplicon was separated on a $0.8 \%$ agarose gel and purified with the QIAquick Gel Extraction Kit (QIAGEN). The Microsynth Company (Switzerland) performed the sequencing using ABI automated sequencers. Chromatograms were corrected manually with DNA Star software (Lasergene, USA). The resulted nucleotide sequence was deposited in the GenBank under accession number MN088860, subjected to Blastn analysis and compared with other related sequences from the NCBI database. Thirty-three sequences with highest similarity to the query were chosen for further phylogenetic analysis.

\section{Phylogenetic analysis}

Multiple sequence alignment of the prokaryotic and eukaryotic species/strains was performed separately by using the ClustalW program built in the phylogenetic software MEGA 7 (Kumar et al., 2016). Phylogenetic trees were computed by MEGA 7 using the maximum-likelihood (ML), and neighbor-joining (NJ) algorithms (Nei and Kumar, 2000). All algorithms were performed with 1000 bootstrap replicates. Nucleotide positions containing gaps and missing data were eliminated from the data set (complete deletion option). Escherichia coli str. K-12 (NR102804) was used as an outgroup for the prokaryotic species/strains. The analysis of the eukaryotic species/strains involved 34 nucleotide sequences.

\section{Phytoplankton counting and biovolumes}

The taxonomic composition of the nano- and microplankton was determined with a light microscope Amplival (magnification up to $1000 \mathrm{x}$ ). Phytoplankton counting was performed on an inverted microscope by the method of Utermöhl (1958). The algal biovolume was determined on the basis of formulas for geometric shapes (Hillebrand et al., 1999). Nano- and microplankton cell size measurements were performed on each species at least on ten individuals. The cell biovolume of picoplankton species were calculated by measuring of 50 cells. The total phytoplankton biovolume was calculated 
as the sum of the biovolumes of all species in each sample. The relative biovolume of the APP community was determined as a percentage of the total biovolume. We accept that the APP community (pro- and eukaryotic members) was dominant when there is a relative biovolume of more than $50 \%$ of the total biovolume, according to Somogyi et al. (2014).

\section{Statistical analysis}

The methodology of generalized additive models (GAMs) (Hastie and Tibshirani, 1990; Stasinopolus et al., 2016) was used to determine the empirical relationships between abundance of APP, total phytoplankton biovolume and abiotic factors. The required computations were performed with the gam and gamlss $\mathrm{R}$ packages developed by these authors (R core team 2019). GAMs allow non-linear relationships between the covariates (predictors) via smoothing spline functions and response as opposed to the traditional generalized linear models in which the predictors are included linearly.

\section{Results}

\section{Environmental conditions and trophic status}

The lagoon is characterized by high summer temperatures, with average values ranging from 19.2 to $24.2^{\circ} \mathrm{C}$ (Table 1$)$. Lowest temperature $\left(7.8^{\circ} \mathrm{C}\right)$ was measured in October 2014, while highest summer temperature $\left(29.8^{\circ} \mathrm{C}\right)$ was measured in July 2015. North Saltern waters are alkaline, with $\mathrm{pH}$ ranging from 8.6 to 9.1. During the summer season, super oxygen saturation was observed, reaching $>200 \%$ in June 2016 as a result of the intensive blooming of APP. Nutrients had constant high levels. The ammonium nitrogen $\left(\mathrm{N}-\mathrm{NH}_{4}\right)$ had highest values in the mid-summer $\left(>1.5 \mathrm{mg} \mathrm{L}^{-1}\right)$. Nitrite nitrogen $\left(\mathrm{N}-\mathrm{NO}_{2}\right)$ increased from spring to summer, while the nitrate nitrogen $\left(\mathrm{N}-\mathrm{NO}_{3}\right)$ was usually under the detection limit. The levels of $\mathrm{P}_{-} \mathrm{PO}_{4}$ were high, which indicates that there is no P-limitation of the phytoplankton.

Table 1. Environmental conditions and chlorophyll-a in 2013-2017

\begin{tabular}{|c|c|c|c|c|c|c|c|c|c|c|c|c|}
\hline & & \multicolumn{11}{|c|}{ Parameter } \\
\hline Year & & $\mathbf{T},{ }^{\circ} \mathrm{C}$ & pH & $\begin{array}{c}\text { DO, } \\
\text { mg L }^{-1}\end{array}$ & OS, \% & \begin{tabular}{|c|}
$\mathrm{C}$, \\
$\mathrm{mS} \mathrm{cm}^{-1}$ \\
\end{tabular} & $\begin{array}{l}\text { S, } \\
\% \text { \% }\end{array}$ & \begin{tabular}{|l|}
$\mathrm{N}-\mathrm{NO}_{2}$, \\
$\mathrm{mg} \mathrm{L}^{-1}$ \\
\end{tabular} & \begin{tabular}{|l}
$\mathrm{N}-\mathrm{NO}_{3}$, \\
$\mathrm{mg} \mathrm{L}^{-1}$ \\
\end{tabular} & $\begin{array}{l}\mathrm{N}-\mathrm{NH}_{4}, \\
\mathrm{mg} \mathrm{L}^{-1}\end{array}$ & $\begin{array}{l}\mathrm{P}^{-\mathrm{PO}_{4}} \text {, } \\
\mathrm{mg} \mathrm{L}^{-1}\end{array}$ & $\begin{array}{l}\text { Chl-a, } \\
\mu g \mathrm{~L}^{-1}\end{array}$ \\
\hline \multirow{3}{*}{2013} & $\min$ & 17.2 & 8.36 & 7.5 & 89.6 & 45.9 & 30.1 & 0.11 & $<0.2$ & 0.13 & 0.60 & 8.7 \\
\hline & $\max$ & 25.1 & 8.7 & 15.4 & 158.9 & 78.3 & 54.3 & 0.21 & & $>1.5$ & 4.5 & 26.7 \\
\hline & mean & 21.1 & 8.6 & 11.1 & 124.8 & 65.3 & 43.6 & 0.15 & & n.a. & 1.97 & 17.7 \\
\hline \multirow{3}{*}{2014} & $\min$ & 7.8 & 8.4 & 10.0 & 116.1 & 60.9 & 39.9 & 0.11 & $<0.1$ & 0.14 & 0.74 & 9.4 \\
\hline & $\max$ & 29.3 & 9.4 & 14.9 & 147.2 & 71.7 & 49.3 & 0.61 & 0.78 & $>1.5$ & 1.8 & 37.8 \\
\hline & mean & 19.2 & 8.8 & 11.9 & 127.6 & 66.1 & 44.5 & 0.26 & n.a. & n.a. & 1.3 & 25.2 \\
\hline \multirow{3}{*}{2015} & $\min$ & 10.0 & 8.4 & 8.1 & 97.3 & 11.4 & 6.3 & 0.08 & $<0.1$ & 0.05 & 0.15 & 1.5 \\
\hline & $\max$ & 29.8 & 8.9 & 14.8 & 129.0 & 60.3 & 40.2 & 0.17 & & 0.74 & 0.85 & 2.1 \\
\hline & mean & 19.6 & 8.6 & 10.5 & 109.8 & 31.6 & 19.8 & 0.12 & n.a. & 0.33 & 0.43 & 1.8 \\
\hline \multirow{3}{*}{2016} & $\min$ & 18.6 & 8.6 & 6.4 & 79.9 & 41.3 & 26.1 & 0.12 & $<0.2$ & 0.14 & 0.27 & 256.3 \\
\hline & $\max$ & 27.6 & 9.5 & 19.7 & $>200$ & 83.1 & 59 & 0.18 & 19.3 & $>1.5$ & 0.69 & 305.6 \\
\hline & mean & 24.1 & 9.1 & 12.1 & 97.9 & 59 & 40 & 0.14 & n.a. & n.a. & 0.48 & 280.9 \\
\hline \multirow{3}{*}{2017} & $\min$ & 17.5 & 8.7 & 7.9 & 72.6 & 62.8 & 41.8 & 0.078 & $<0.2$ & 0.12 & 0.08 & 331.7 \\
\hline & $\max$ & 29.6 & 9.1 & 16.6 & 172.5 & 128.6 & $>72$ & 0.153 & & $>1.5$ & 0.21 & 400.6 \\
\hline & mean & 24.2 & 8.9 & 11.3 & 136.4 & 97.6 & n.a. & 0.12 & n.a. & n.a. & 0.16 & 366.2 \\
\hline
\end{tabular}

Legend: Temperature (T), Dissolved oxygen (DO), Oxygen saturation (OS), Conductivity (C), Salinity

(S), Chlorophyll-a (Chl-a), n.a. - not applicable 
Chlorophyll- $a$ varied in an extremely wide range from 1.8 to $366.2 \mu \mathrm{g} \mathrm{L} \mathrm{L}^{-1}$, but in the prevailing part of the study period indicated hypertrophic conditions according to the fixed boundary system on an OECD report (OECD, 1982). Salinity was controlled by the technological requirements for salt production and naturally increases from spring to autumn. Due to the shallow nature of the lagoon, salinity was strongly influenced by the meteorological conditions, e.g. after a rainy spring in 2015 , the salinity reached $40.2 \%$ o only in September. The same year, the mid-seasonal salinity had a minimum value of $19.8 \%$, which corresponds to the mixosaline zone. With exception of 2015, the average salinity of North Saltern was above $40 \%$, which is typical for the hypersaline waters. The extreme variations of the salinity in North Saltern over the five-year study period ranged from 6.3 to $>72 \%$.

\section{Identification of the prokaryotic APP}

The 16S DNA sequence analysis of the strain PACC 8945 showed a high percentage of identitties with NCBI 16S rDNA sequences belonging to genus Synechococcus. Since the taxonomy of the order Synechococcales and in particular of the genus Synechococcus is still problematic, the obtained in this study nucleotide sequence (MN061337) was also used for phylogenetic analyses. For the purpose of the phylogenetic analyses, sequences of representatives of the genera Synechococcus (freshwater, marine and species inhabiting waters with very high salinity), Prochlorococcus, Cyanobium and the newly proposed Parasynechococcus were selected.

Determination of the phylogenetic position of different taxa is the first and most important criterion in the classification process. The most commonly used moleculargenetic marker that provides an excellent framework for testing phylogenetic hypotheses is the $16 \mathrm{~S}$ rRNA gene. The phylogenetic tree obtained from the ML analysis in this study is shown in Figure 2. Four distinct clades could be distinguished in the phylogenetic reconstruction, here named Clade 1, Clade 2, Clade 3, and Clade 4 (Fig. 2). The first clade (Clade 1) comprises Synechococcus marine strains and strains suggested as members of a new genus Parasynechococcus (Coutinho et al., 2016). The representatives of genus Parasynecococcus are not monophyletic, but rather showed polyphyly, being scattered in the phylogenetic tree. These phylogenetic positions do not confirm the separation of Parasynecococcus as a new genus. The topology demonstrates the need of new markers that, in combination with 16S DNA, could contribute to solving such problems.

The second clade (Clade 2) includes the studied PACC 8945 strain, which is positioned close to a strain isolated from a hypersaline water reservoir in Romania and strains isolated from the Red Sea and the Pacific Ocean, each with salinity between 36 and $55 \mathrm{~g} \mathrm{~L}^{-1}$ (Keresztes et al., 2012; Coutinho et al., 2016).

Clade 3 combines representatives of the genus Prochlorococcus (Prochlorococcus marinus). The phylogenetic tree shows pronounced monophily and potential for distinguishing between low light intensity (LLI) and high light intensity (HLI) strains of genus Prochlorococcus. Clade 4 consists of freshwater cyanobacterial strains of the genera Synechococcus and Cyanobium. The phylogenetic reconstruction based on the neighbor-joining (NJ) algorithm showed a similar topology. 


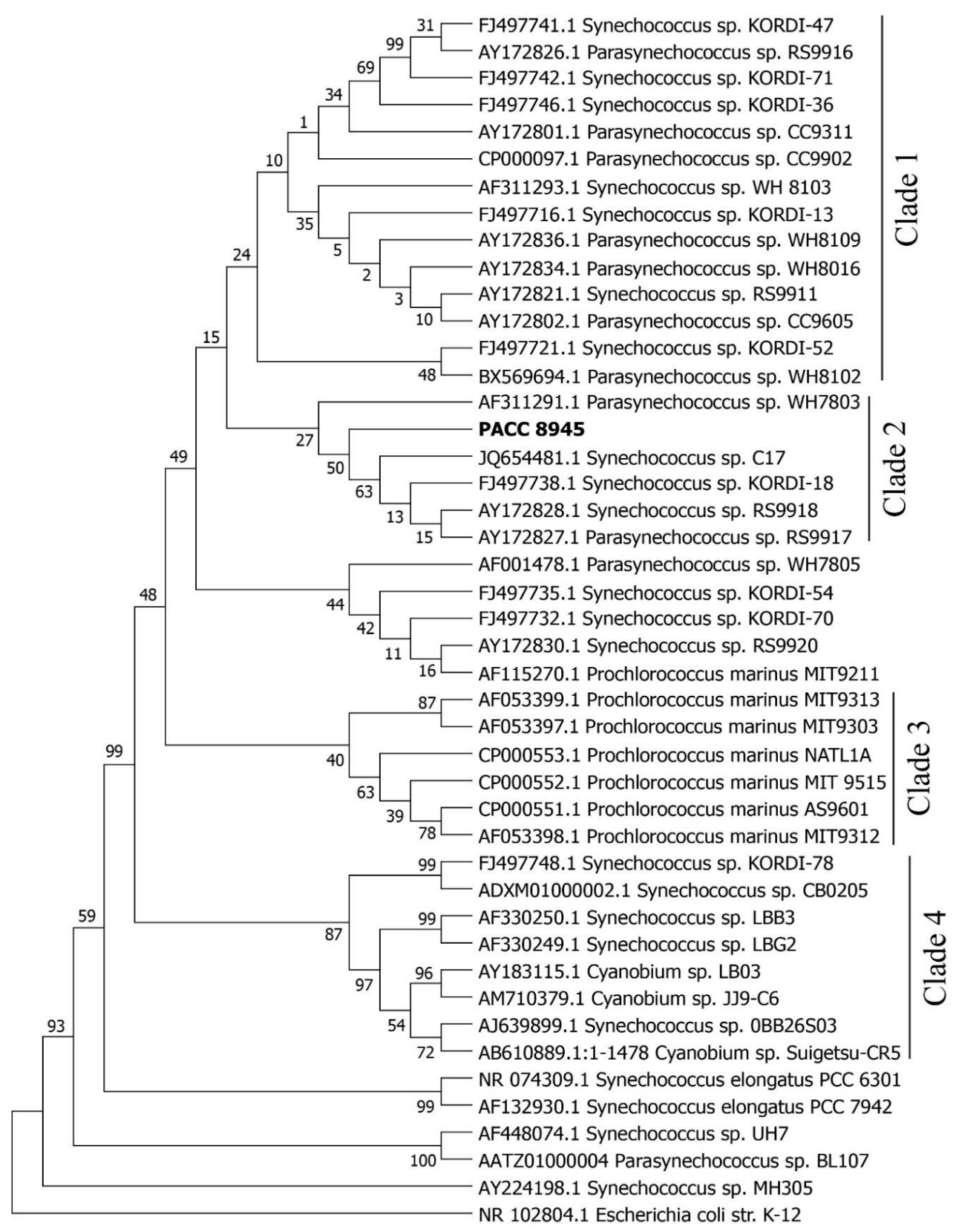

Figure 2. A Maximum-Likelihood (ML) phylogenetic tree based on 16S DNA sequences. The analysis includes 16S DNA sequences of cyanobacterial strains from the genera Synechococcus, Prochlorococcus, Cyanobium, Parasynechococcus. Numbers show the bootstrap support. The I6S DNA sequence of E coli str. K-12 was used as an outgroup. Access numbers in GenBank are given before the name of the species

\section{Identification of the eukaryotic APP}

For analysis of the phylogenetic relationships and for construction of the phylogenetic tree, 18S DNA sequences from different genera that have been shown homology with the target nucleotide sequence were selected.

The applied selection included the following genera Picochlorum, Nanochlorum, Nannochloris, Pseudochloris, Marvania, Chlorella, Auxenochlorella and Coccomyxa. 
The phylogenetic tree (Fig. 3) consisted of 2 clades: the main clade, including species from genera Picochlorum, Nanochlorum and Nannochloris, and clade 2, which contains species of the taxonomically distant genera Pseudochloris, Marvania, Chlorella and Auxenochlorella.

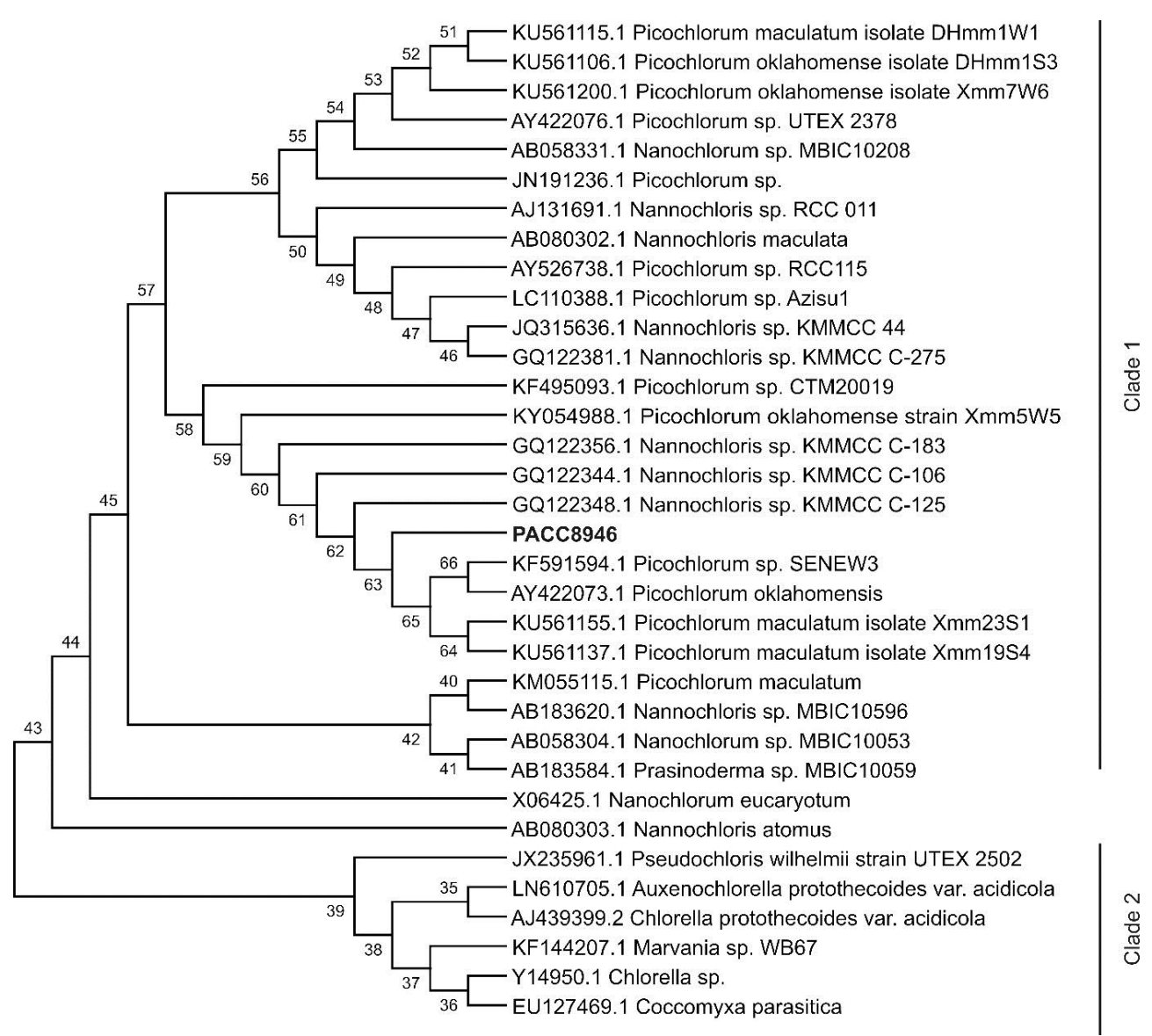

Figure 3. Molecular phylogenetic analysis based on $18 S$ DNA sequences of species from the genera Picochlorum, Nanochlorum, Nannochloris, Prasinoderma, Pseudochloris, Auxenochlorella, Chlorella, Marvania and Coccomyxa. The tree with the highest log likelihood is shown

Studied isolate PACC 8946 indicated practical identity of the 18S DNA sequence with the holotype of Picochlorum oklahomense (GenBank accession AY422073) and Picochlorum sp. SENEW3 (GenBank accession KF591594) from a poikilohaline pond of San Elijo Lagoon, USA (Henley et al., 2004; Wang et al., 2014).

The cytomorphological features of the eukaryotic species (strain PACC 8946) revealed also similarity with Picochlorum oklahomense. We observed small rounded cells $(\mathrm{d}=2-3 \mu \mathrm{m})$ with one laterale chloroplast, without pyrenoide (Fig. 4A,B). Reproduction was carried out by autosporulation into two or four daughter cells (Fig. 4C,D). The mother cells reached approximately $5 \mu \mathrm{m}$ in size.

Following the polyphasic approach of the current classification and taking in account the genetic similarity of strain PACC 8946 with Picochlorum oklahomense, and similarity in the cytomorphological and ecological markers, we identified the eukaryotic assemblage of APP from the North Saltern as Picochlorum oklahomense Hironaka. 


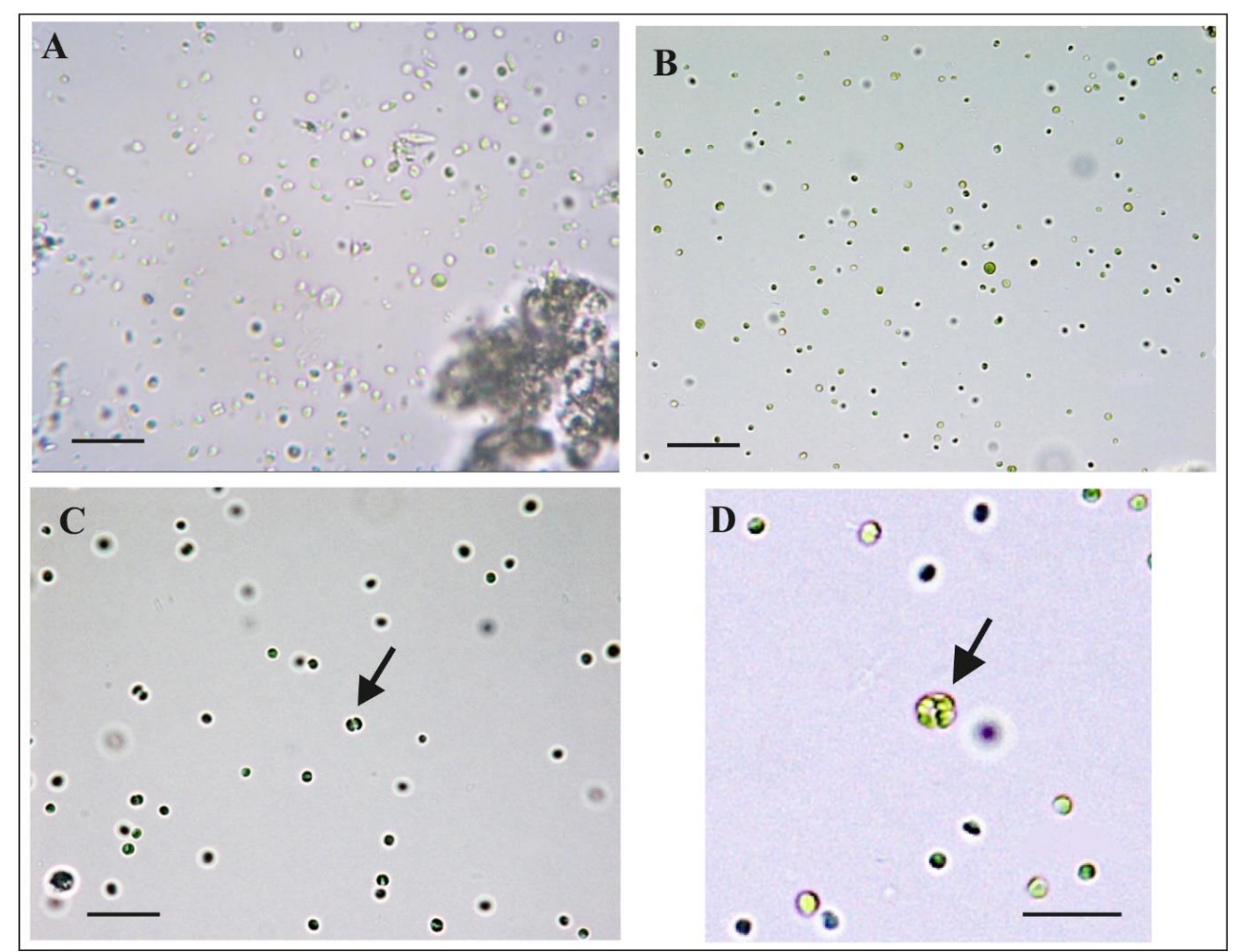

Figure 4. Photomicrographs of Picochlorum oklahomense. A: Field sample, containing spherical cells of Picochlorum, Synechococcus and pennate diatom; B, C, D: Picochlorum oklahomense, strain PACC 8946, isolated from field sample, collected in Atanasovsko Lake; $\boldsymbol{C}$ :

Autosporulation into two daughter cells; D: Autosporulation into four daughter cells. The arrow indicates autosporulation. Scale bars $=10 \mu \mathrm{m}$

\section{Taxonomic composition, abundance and biovolume of the phytoplankton community}

During the study period, we found a small number of species (from 10 to 19), which belonged to seven taxonomic groups: Cyanobacteria, Prasinophyceae, Trebouxiophyceae, Chlorophyceae, Bacillariophyceae, Dinophyceae and Cryptophyceae (Table 2). Common species that accompanied the APP throughout the study period were diatoms (Cocconeis placentula, Cylindrotheca closterium, Triblionella punctata and Planothidium delicatulum), green algae (Oocystis sp.) and the dinoflagellate Katodinium fungiforme.

The total biovolume of the phytoplankton varied within a very wide range - from 0.6 to $121.7 \mathrm{~mm}^{3} \mathrm{~L}^{-1}$ (2015 and 2016, respectively) (Table 3). With exception of 2015, APP community was dominant, forming above $50 \%$ of the total biovolume. Highest midseasonal levels of the total biovolume $\left(65.4 \mathrm{~mm}^{3} \mathrm{~L}^{-1}\right)$ were recorded in 2016 , when the APP formed over $93 \%$ from the biovolume. The contribution of the APP to the total phytoplankton biovolume reached a maximum value of $99.3 \%$ in July $2016\left(\mathrm{~T}=27.6^{\circ} \mathrm{C}\right.$; $\mathrm{S}=59 \%$ ). During the same month, the APP was in a state of intensive blooming, with an extremely high abundance of $240.1 \times 10^{6}$ cells $\mathrm{mL}^{-1}$. We found that a key factor for the intensive blooms of APP in 2016 was the salinity range 30-59\%, combined with the higher average annual temperature of $24.1^{\circ} \mathrm{C}$ (Table 1). Conversely, in 2015, the relative biovolume of APP accounted for only $1 / 3$ of the total biovolume and the abundance of APP was significantly lower: mean $0.16 \times 10^{6}$ cells $\mathrm{mL}^{-1}$. 
Table 2. Main cyanobacterial and algal morphotypes in Atanasovsko Lake during the period 2013-2017

\begin{tabular}{|c|c|c|c|c|c|}
\hline Year & 2013 & 2014 & 2015 & 2016 & 2017 \\
\hline Cyanobacteria & & & & & \\
\hline Prokaryotic APP & $\bullet$ & $\bullet$ & $\bullet$ & - & $\bullet$ \\
\hline $\begin{array}{l}\text { Komvophoron breve } \\
\text { Merismopedia punctata }\end{array}$ & - & - & 0 & & - \\
\hline Phormidium bulgaricum & - & & & & $\bullet$ \\
\hline Phormidium chlorinum & & & - & & \\
\hline Pseudanabaena minima & & - & - & - & - \\
\hline Prasinophyceae & & & & & \\
\hline Polyblepharides amylifera & & & $\bullet$ & & \\
\hline $\begin{array}{c}\text { Pyramimonas micron } \\
\text { Trebouxiophyceae }\end{array}$ & & - & & - & - \\
\hline Eukaryotic APP & - & - & - & - & - \\
\hline $\begin{array}{c}\text { Closteriopsis acicularis } \\
\text { Oocystis sp. }\end{array}$ & $\bullet$ & $\bullet$ & $\bullet$ & $\bullet$ & $\bullet$ \\
\hline Provasoliella ovata & & & & & $\bullet$ \\
\hline $\begin{array}{c}\text { Chlorophyceae } \\
\text { Monoraphidium griffithii }\end{array}$ & & & $\bullet$ & & \\
\hline Monoraphidium arcuatum & & & - & & \\
\hline $\begin{array}{l}\text { Bacillariophyceae } \\
\text { Amphora sp. }\end{array}$ & & $\bullet$ & & $\bullet$ & ๑ \\
\hline Cocconeis placentula & & $\bullet$ & - & 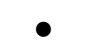 & $\bullet$ \\
\hline Cyclotella caspia & & - & • & $\bullet$ & - \\
\hline Cylindrotheca closterium & - & - & - & - & - \\
\hline Navicula capitatoradiata & & 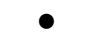 & & & - \\
\hline Nitzschia longissima & - & - & - & - & - \\
\hline Planothidium delicatulum & - & - & - & - & - \\
\hline $\begin{array}{l}\text { Triblionella punctata } \\
\text { Dinophyceae }\end{array}$ & - & - & - & - & - \\
\hline Katodinium fungiforme & $\bullet$ & $\bullet$ & $\bullet$ & - & - \\
\hline Cryptophyceae & & & & & \\
\hline $\begin{array}{l}\text { Hillea fusiformis } \\
\text { Teleaulax acuta }\end{array}$ & & $\bullet$ & $\bullet$ & $\bullet$ & $\bullet$ \\
\hline
\end{tabular}

Table 3. Parameters of the phytoplankton community in Atanasovsko Lake during the period 2013-2017

\begin{tabular}{|c|c|c|c|}
\hline Date & TB, $\mathbf{m m}^{3} \mathrm{~L}^{-1}$ & CAPPTB, \% & AbAPP,$\times 10^{6}$ cells $\mathrm{mL}^{-1}$ \\
\hline 12 June 2013 & 8.7 & 58.0 & 1.62 \\
\hline 29 July 2013 & 16.8 & 72.2 & 4.62 \\
\hline 01 Sept.2013 & 26.7 & 83.8 & 5.43 \\
\hline 10 June 2014 & 4.1 & 75.4 & 0.74 \\
\hline 19 July 2014 & 15.8 & 88.0 & 2.63 \\
\hline 13 Sept. 2014 & 12.3 & 59.2 & 2.12 \\
\hline 17 June 2015 & 0.6 & 36.6 & 0.13 \\
\hline 27 July 2015 & 0.8 & 35.1 & 0.18 \\
\hline 09 June 2016 & 62.2 & 97.0 & 32.30 \\
\hline 27 July 2016 & 121.7 & 99.3 & 240.11 \\
\hline 16 Sept. 2016 & 12.4 & 84.1 & 5.48 \\
\hline 10 June 2017 & 36.1 & 98.5 & 7.10 \\
\hline 21 July 2017 & 5.3 & 13.8 & 1.15 \\
\hline 11 Sept. 2017 & 55.5 & 51.1 & 6.00 \\
\hline
\end{tabular}

Abbreviations: TB (Total biovolume); CAPPTB (Contribution of APP to the total phytoplankton biovolume); AbAPP (Abundance of APP) 


\section{Statistical analysis}

Marked correlations in bold (Table 4) are significant at p-value $<0.05$. There is a strong linear relationship between the response of variables $\mathrm{C}$ (Conductivity) and $\mathrm{S}$ (Salinity), total phytoplankton biovolume (TB) and abundance of APP (AbAPP). The correlations between the explanatory variables (covariates) $\mathrm{T}$ (temperature), $\mathrm{C}, \mathrm{S}, \mathrm{N}$ $\mathrm{NO}_{2}, \mathrm{~N}-\mathrm{NO}_{3}, \mathrm{~N}-\mathrm{NH}_{4}, \mathrm{P}-\mathrm{PO}_{4}$ and the response variables TB, AbAPP, CAPPTB (Contribution of APP to the total phytoplankton biovolume) is not significant. This means that the relationship between the response and covariates is not linear.

Table 4. Pearson correlation matrix

\begin{tabular}{|c|c|c|c|c|c|c|c|c|c|c|}
\hline & $\mathbf{T}$ & $\mathrm{C}$ & $\mathbf{S}$ & $\mathrm{N}-\mathrm{NO}_{2}$ & \begin{tabular}{|l}
$\mathrm{N}-\mathrm{NO}_{3}$ \\
\end{tabular} & N-NH4 & $\mathbf{P}-\mathrm{PO}_{4}$ & AbAPP & TB & CAPPTB \\
\hline $\mathbf{T}$ & 1.00 & 0.18 & 0.13 & -0.03 & -0.25 & 0.18 & -0.61 & 0.18 & 0.09 & -0.36 \\
\hline C & 0.18 & 1.00 & 0.96 & 0.12 & -0.01 & 0.48 & -0.15 & 0.13 & 0.33 & -0.04 \\
\hline $\mathbf{S}$ & 0.13 & 0.96 & 1.00 & 0.06 & 0.02 & 0.50 & -0.13 & 0.22 & 0.34 & 0.03 \\
\hline $\mathrm{N}-\mathrm{NO}_{2}$ & -0.03 & 0.12 & 0.06 & 1.00 & 0.38 & 0.22 & 0.13 & 0.34 & 0.36 & -0.03 \\
\hline $\mathrm{N}-\mathrm{NO}_{3}$ & -0.25 & -0.01 & 0.02 & 0.38 & 1.00 & 0.22 & -0.07 & -0.09 & -0.11 & -0.08 \\
\hline $\mathrm{N}-\mathrm{NH}_{4}$ & 0.18 & 0.48 & 0.50 & 0.22 & 0.22 & 1.00 & 0.26 & 0.17 & 0.06 & -0.13 \\
\hline $\mathrm{P}_{-} \mathrm{PO}_{4}$ & -0.61 & -0.15 & -0.13 & 0.13 & -0.07 & 0.26 & 1.00 & -0.10 & -0.11 & 0.18 \\
\hline AbAPP & 0.18 & 0.13 & 0.22 & 0.34 & -0.09 & 0.17 & -0.10 & 1.00 & 0.87 & 0.40 \\
\hline TB & 0.09 & 0.33 & 0.34 & 0.36 & -0.11 & 0.06 & -0.11 & 0.87 & 1.00 & 0.54 \\
\hline САРPТВ & -0.36 & -0.04 & 0.03 & 0.03 & -0.08 & -0.13 & 0.18 & 0.40 & 0.54 & 1.00 \\
\hline
\end{tabular}

Abbreviations: T (Temperature); C (Conductivity); S (Salinity), AbAPP (Abundance of APP), TB (Total biovolume); CAPPTB (Contribution of APP to the total phytoplankton biovolume)

The generalized additive models (GAMs) allow non-linear relationships between the responses AbAPP, TB and smoothing spline functions of the covariates $\mathrm{T}, \mathrm{S}, \mathrm{N}-\mathrm{NO}_{2}$, $\mathrm{N}-\mathrm{NO}_{3}, \mathrm{~N}-\mathrm{NH}_{4}$ and $\mathrm{P}_{-} \mathrm{PO}_{4}$. Only the cubic spline functions of the covariates $\mathrm{T}$ and $\mathrm{S}$ are highly significant and the response TB within GAMs model with gamma distribution and log-link function. Deviance explained by this model is $87 \%$ whereas the correlation between measured and model predicted values is 0.71. Similarly, the GAMs model with log-link function, response AbAPP and cubic spline functions of the covariates $\mathrm{T}$ and $\mathrm{S}$ explain $88 \%$ of the deviance whereas the correlation between measured and model predicted values is 0.76 . The parameter estimates, standard errors, parameter estimates divided by their estimated standard errors, $p$-value and significant codes are given in Table 5. The AbAPP and TB measured and predicted values are presented in Table 6.

Table 5. GAMs model: response variables $T B$ and AbAPP, cubic spline models of the covariates temperature $(T)$ and salinity $(S)$

\begin{tabular}{|c|c|c|c|c|c|c|c|c|c|c|}
\hline $\begin{array}{c}\text { Gamma } \\
\text { distribution terms }\end{array}$ & Estimate & $\begin{array}{c}\text { Std. } \\
\text { error }\end{array}$ & $t$ value & 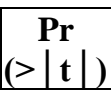 & Sc. & Estimate & \begin{tabular}{|c|} 
Std. \\
error
\end{tabular} & $t$ value & $\operatorname{Pr}(>|\mathbf{t}|)$ & Sc. \\
\hline & \multicolumn{5}{|c|}{ TB } & \multicolumn{5}{|c|}{ AbAPP } \\
\hline $\begin{array}{c}\mu \text { link function: } \\
\qquad \log \end{array}$ & & & & & & & & & & \\
\hline Intercept & $\begin{array}{c}2.115 \\
-0.099\end{array}$ & 0.854 & $\begin{array}{c}2.476 \\
-3.134\end{array}$ & $\begin{array}{l}0.076 \\
0.042\end{array}$ & & $\begin{array}{c}2.022 \\
-0.135\end{array}$ & $\begin{array}{l}1.245 \\
0.048\end{array}$ & $\begin{array}{c}1.624 \\
-2843\end{array}$ & 0.178 & \\
\hline $\begin{array}{l}\operatorname{cs}(\mathbf{T}) \\
\operatorname{cs}(\mathbf{S})\end{array}$ & $\begin{array}{c}-0.069 \\
0.064\end{array}$ & $\begin{array}{l}0.032 \\
0.008\end{array}$ & $\begin{array}{l}-3.134 \\
7.780\end{array}$ & $\begin{array}{l}0.042 \\
0.002\end{array}$ & $* *$ & $\begin{array}{c}-0.135 \\
0.059\end{array}$ & $\begin{array}{l}0.048 \\
0.012\end{array}$ & $\begin{array}{c}-2.843 \\
4.875\end{array}$ & $\begin{array}{l}0.04 / \\
0.008\end{array}$ & $* *$ \\
\hline $\begin{array}{c}\text { Scale link } \\
\text { function - log } \\
\text { Intercept }\end{array}$ & -0.821 & 0.183 & -4.483 & 0.014 & * & -0.440 & 0.178 & -2.482 & 0.068 & \\
\hline
\end{tabular}

Significance codes $(\mathrm{Sc})$ : ‘**' $0.01^{\text {' } * \text { ’ } 0.05}$ 
Table 6. The measured and GAMs model predicted values with response variables $T B$ and $A b A P P$, and cubic spline functions of the covariates temperature $(T)$ and salinity $(S)$

\begin{tabular}{c|c|c|c|c}
\hline Case & Observed TB & $\begin{array}{c}\text { Predicted } \\
\text { TB }\end{array}$ & $\begin{array}{c}\text { Observed } \\
\text { AbAPP }\end{array}$ & $\begin{array}{c}\text { Predicted } \\
\text { AbAPP }\end{array}$ \\
\hline 1 & 8.73 & 11.69 & 1.62 & 1.57 \\
2 & 16.81 & 16.97 & 4.62 & 4.99 \\
3 & 26.68 & 27.99 & 5.43 & 5.91 \\
4 & 4.14 & 4.213 & 0.74 & 0.77 \\
5 & 15.76 & 14.89 & 2.63 & 4.53 \\
6 & 12.31 & 10.93 & 2.12 & 1.44 \\
7 & 0.58 & 0.73 & 0.13 & 0.14 \\
8 & 0.81 & 0.94 & 0.18 & 0.24 \\
9 & 62.21 & 37.71 & 32.30 & 23.37 \\
10 & 121.73 & 78.50 & 240.11 & 107.35 \\
11 & 12.38 & 81.18 & 5.48 & 102.89 \\
12 & 36.08 & 30.09 & 7.10 & 6.92 \\
13 & 5.34 & 5.496 & 1.15 & 0.87 \\
14 & 55.52 & 57.47 & 6.00 & 14.69 \\
\hline
\end{tabular}

These GAMs results are preliminary of an ongoing and extended study and should be considered with caution because of the small time-series sample size.

\section{Discussion}

North Saltern waters are alkaline, rich in ammonium nitrogen (often above the detection range) and phosphate (Table 1). Similar high nutrient levels have been reported by Wang et al. (2014) for the San Elijo lagoon, California. The high biogenic load of the lagoons is due to the long water stay and thus the repeated nutrient recycling (Kennish and Paerl, 2010). An additional source of nitrogen and phosphorus loading may be wintering and migrating aquatic birds (Boros et al., 2008), which have high abundance in Atanasovsko Lake as part of the Via Pontica migration route. Salinity of the North Saltern increased naturally from spring to autumn every year, and this cyclic pattern is also characteristic of other lagoons (Wang et al., 2014). Due to the shallow nature of the lake $(0.3 \mathrm{~m})$, salinity was strongly influenced by the meteorological conditions (Hubenov et al., 2015). In the last two years, the average seasonal values of chlorophyll- $a$ have been in the range of hypereutrophic conditions (Table 1). According to Kennish and Paerl (2010) many coastal lagoons are eu- and even hypertrophic.

The APP community in North Saltern was represented by small $(2-3 \mu \mathrm{m})$ spherical to oval or cylindrical cells (Fig. 4A), which cannot be identified by using the classical optical miscroscopy. The reviewed literature showed that pico-sized taxa $(<3 \mu \mathrm{m})$ are evaluated via convergent evolution and are characterized by extremely high phylogenetic and physiological diversity (Krienitz et al., 2012; Somogyi et al., 2013). Following the application of molecular genetic methods for Class Trebouxiophyceae, a number of marine or saline picoplankton species belonging to the genera Picochlorum, Chloroparva and Pseudochloris have been identified (Henley et al., 2004; Somogyi et al., 2011, 2013). A large variety of marine coccoid picoplankton lines was also found in Prasinophyceae (Krienitz et al., 2012). Mychonastes spesies (Chlorophyceae) were described from brackish and fresh waters. 
The conducted molecular-genetic and phylogenetic analyses proved that the APP in Atanasovsko Lake is an assemblage of two basic genotypes: Picochlorum oklahomense Hironaka (Chlorophyta, Trebouxiophyceae) and marine Synechococcus sp. (Synechococcales, Cyanobacteria). This finding was confirmed by cytomorphological charateristics of the cultures and ecological data. At present, the species Picochlorum oklahomense have been reported from very distinct and isolated habitats. They are parts of limno- and halosphere, such as the saline pool in Salt Plains National Wildlife Refuge of Oklahoma, USA (Henley et al., 2004), inland hypersaline lakes in Romania (Keresztes et al., 2012) and the coastal lagoon in southern California (Wang et al., 2014). These isolated habitats provide specific conditions for development of ensembles dominated by Picochlorum oklahomense and marine Synechococcus sp. (in Transylvanian lakes, Romania and Atanasovsko Lake, Bulgaria) or Picocystis salinarum (San Elijo lagoon, California). Confirmed habitats have the following common characteristics: shallow, with variable salinity, hypertrophic and with high summer temperatures. Three of them (San Elijo lagoon, salt pans of Oklahoma and Atanasovsko lake) maintain high abundance from waterfowl. This confirmed the suggestion of Keresztes et al. (2012) that the distribution of picoplankton species between isolated habitats is via waterfowl transfer.

The low number of associated phytoplankton species included representatives from 7 taxonomic groups (Table 2). Most of these species are cosmopolitan in marine or salty waters, euryhaline - e.g. diatoms Cylindrotheca closterium, Triblionella punctata, prasinophycean Polyblepharides amylifera, Pyramimonas micron (Ettl, 1983; Popovský and Pfiester, 2008). They were reported from coastal, inland haline lakes or freshwater basins with high mineralization. In 2015, the year with decreased salinity $-19.8 \%$ o (Table 1), we identified species that are widespread in freshwater (sometimes also in slight salty) habitats as cyanobacteria Merismopedia punctata, Phormidium chlorinum and green algae Monoraphidium griffithii, M. arcuatum and Closteriopsis acicularis (Komárek and Fott, 1983; Komárek and Anagnostidis, 1999, 2005). According to Vadrucci et al. (2013), the large gradient of salinity and biogenic load are the most important factors that select taxonomic composition in coastal lagoons. Phytoplankton communities in coastal lagoons exhibit high inter- and intra-ecosystem taxonomic heterogeneity due to their spatial and temporal variability in the hydrogeological and geomorphological characteristics. This makes harder the development of indices for assessment of the ecological status of coastal lagoons.

During the 5-year period, the phytoplankton community in North Saltern was dominated by APP, which often reached extremely high abundance - from $10^{6}$ to $10^{8}$ cells $\mathrm{mL}^{-1}$ (Table 3), to a state of visible blooming of water (Fig. 1C). The high abundance of APP in shallow, turbid lakes is explained by the increased surface-tovolume ratio of the cells, which provides better utilization of light and more efficient absorption of nutrients (Felföldi et al., 2009). Similar abundance of the APP $\left(10^{6}\right.$ to $10^{8}$ cells $\mathrm{mL}^{-1}$ ) and share in total biomass $90-100 \%$ was reported by Felföldi et al. (2009) for eutrophic shallow lakes similar to the Atanasovsko Lake. The results showed that the contribution of APP to the total biovolume is highly variable (from 36 to 99\%) Table 3. Concerning the ecological factor abundance of APP a nonparametric regression model is proposed between the response abundance of APP and the salinity and temperature (Table 5) as the main abiotic drivers. In a study of picoplankton dynamics in an Australian lagoon, Schapira et al. (2010) also identified salinity as a key factor in the abundance of APP. 
We registered highest APP abundance in 2016 at salinity range 30-59\%o and average summer temperatures above $24^{\circ} \mathrm{C}$ (Tables 1 and 3). These conditions stimulated the blooms of the picoplankton with a contribution of APP to the total phytoplankton biovolume $>93 \%$. As an ecological optimum for APP predominance (over 99\% of total biovolume) we defined salinity $59 \%$ and temperature $27.6^{\circ} \mathrm{C}$, at which the abundance of APP reached values similar with the reported maximum $\left(1.08 \times 10^{8}\right.$ cells $\left.\mathrm{mL}^{-1}\right)$ in extremely shallow turbid soda lakes (Somogyi et al., 2009). Temperature values in the lake during 2016 were close to the optimum growth temperature of $30^{\circ} \mathrm{C}$ in cultures of Picochlorum sp., strain SENEW3 (Wang et al., 2014).

Concerning salinity, the wide-ranging halotolerance of Picochlorum oklahomense is well known and accepted as an important species-specific ecological characteristic (Henley et al., 2004; Wang et al., 2014). Although in culture experiments Wang et al. (2014) found that the growth rate of Picochlorum sp. (SENEW3) decreases at salinity values above $50 \%$, in our samples from Atanasovsko Lake the optimum salinity appears to be higher (59\%). In natural samples from Cabdic Lake (Romania), the coexistence Picochlorum oklahomense/Synechococcus sp. was found at similar to the Atanasovsko Lake physico-chemical conditions: temperature $=28.2^{\circ} \mathrm{C}$ and salt concentration $55 \mathrm{~g} \mathrm{~L}^{-1}$ (Keresztes et al., 2012).

\section{Conclusions}

Due to the extremely small size $(2-3 \mu \mathrm{m})$ and the lack of sufficient morphological features for taxonomic identification, the APP species in North Saltern of Atanasovsko Lake were identified by molecular and phylogenetic analyzes of 16S/18S DNA. The APP species showed genotype identity with marine Synechococcus sp. (Synechococcales, Cyanobacteria) and Picochlorum oklahomense (Trebouxiophyceae, Chlorophyta). Our analysis demonstrated the possibility to apply these molecular methods for identification of picoplankton species from natural sample isolates.

By using a polyphasic approach, based on molecular, morphological and ecological characteristics of natural samples and isolates, we collected data for the Picochlorum oklahomese/Synechococcus sp. assemblage. This is the first report for Picochlorum oklahomese and marine Synechococcus sp. as part of APP in a European coastal lagoon. North Saltern is characterized by a continuous salinity gradient in the limits of mixo- to hypersalinity zone (6.3 to $72 \%$ ). Waters are alkaline, with high levels of nutrients (ammonia, phosphate) and high summer temperatures.

The main abiotic drivers that control the taxonomic composition and abundance of the APP are salinity and temperature. Salinity between 30 and 59\%o and an average summer temperature above $24^{\circ} \mathrm{C}$ provide an ecological optimum for growth of APP at a relative biovolume $>93 \%$.

We think that APP, in which Picochlorum oklahomese is associated with Synechococcus sp. or Picocystis salinarum is distributed in more coastal lagoons or inland hypersaline lakes with similar to the Atanasovsko Lake characteristics. We suggest that the distribution of the picoplankton species is related to the waterfowl and these picoplankton species may be found in more habitats with a high abundance of waterfowl or along their migration routes.

Future research on the taxonomic composition of autotrophic picoplankton in coastal lagoons and salt marshes needs to be expanded, since it plays a key role as a primary producer. 
Acknowledgments. This work was supported by the Bulgarian National Science Fund (research grant DN 01/2) and the project LIFE11 NAT/BG/000262 with the acronym Salt of Life.

\section{REFERENCES}

[1] Agustí, S. (1991): Allometric scaling of light absorption and scattering by phytoplankton cells. - Canadian Journal of Fisheries and Aquatic Sciences 48: 763-767. https://doi.org/10.1139/f91-091.

[2] Andersen, R., Kawachi, M. (2005): Traditional Microalgae Isolation Techniques. - In: Andersen, R. (ed.) Algal Culturig Techniques. Elsevier Academic Press, Burlington.

[3] Anonymous (1958): The Venice system for the classification of marine waters according to salinity. - Limnology and Oceanography 3: 346-347. https://doi.org/10.4319/lo.1958.3.3.0346.

[4] Ayadi, H., Abid, O., Elloumi, J., Bouaïn, A., Sime-Ngando, T. (2004): Structure of the phytoplankton in two lagoons of different salinity in the Sfax saltern (Tunisia). - Journal of Plankton Research 26: 669-679. https://doi.org/10.1093/plankt/fbh047.

[5] Barnes, R. S. K. (1980): Coastal Lagoons. - Cambridge University Press, Cambridge.

[6] Boros, E., Nagy, T., Pigniczki, C., Kotymán, L., Balogh, K. V., Vörös, L. (2008): The effect of aquatic birds on the nutrient load and water quality of soda pans in Hungary. Acta Zoologica Hungarica 54(S1): 207-224.

[7] Botev, I. (1997): Hydrological regime of Atanasovsko Lake. - In: Michev, T. (ed.) Ecology and Conservation of Atanasovsko Lake Nature Reserve. Collection of Final Scientific Reports of Experts. BSBCP, Sofia, pp. 10-17. (in Bulgarian).

[8] Coutinho, F., Tschoeke, D. A., Thompson, F., Thompson, C. (2016): Comparative genomics of Synechococcus and proposal of the new genus Parasynechococcus. - PeerJ 4(3): e1522. https://doi.org/10.7717/peerj.1522.

[9] Eddy, B. P. (1956): The suitability of some algae for mass cultivation for food, with special reference to Dunaliella bioculata. - Journal of Experimental Botany 21: 372-380. https://doi.org/10.1093/jxb/7.3.372.

[10] Elloumi, J., Carrias, J. F., Ayadi, H., Sime-Ngando, T., Bouaïn, A. (2009): Communities structure of the planktonic halophiles in the solar saltern of Sfax, Tunisia. - Estuarine Coastal and Shelf Science 81(1): 19-26. https://doi.org/10.1016/j.ecss.2008.09.019.

[11] Estrada, M., Peter, H., Gasol, M. J., Casamayor, O. E., Pedrós-Alió, C. (2004): Diversity of planktonic photoautotrophic microorganisms along a salinity gradient as depicted by microscopy, flow cytometry, pigment analysis and DNA-based methods. - FEMS Microbiology Ecology 49: 281-293. https://doi:10.1016/j.femsec.2004.04.002.

[12] Ettl, H. (1983): Chlorophyta I, Phytomonadina. - In: Ettl, H., Gerloff, J., Heynig, H., Mollenhauer, D. (eds.) Süßwasserflora von Mittelueropa Bd. 9. VEB Gustav Fischer Verlag, Jena.

[13] Felföldi, T., Somogyi, B., Márialigeti, K. L., Vörös, L. (2009): Characterization of photoautotrophic picoplankton assemblages in turbid, alkaline lakes of the Carpathian Basin (Central Europe). - Journal of Limnology 68: 385-395. https://doi.org/10.4081/jlimnol.2009.385.

[14] Gecheva, G., Varadinova, E., Belkinova, D., Michov, S., Gyuzelev, G., Hristeva, Y. (2017): Ecological status assessment of a hypersaline lake: case study of Atanasovsko Lake, Bulgaria. - Acta Zoologica Bulgarica 8: 145-151.

[15] Hastie, T. J., Tibshirani, R. J. (1990): Generalized Additive Models. - $1^{\text {st }}$ ed. Boca Raton, Florida: Chapman \& Hall/CRC.

[16] Henley, W. J., Hironaka, J. L., Guillou, L., Buchhem, M. A., Buchhem, I. A., Fawley, M. W., Fawley, K. P. (2004): Phylogenetic analysis of the 'Nannochioris-like' algae and diagnoses of Picochiorum okiahomensis gen. et sp. nov. (Trebouxiophyceae, Chlorophyta). - Phycologia 43: 641-652. https://doi.org/10.2216/i0031-8884-43-6-641.1. 
[17] Hillebrand, H., Dürseken, D., Kirschtel, D., Pollingher, U., Zohary, T. (1999): Biovolume calculation for pelagic and benthic microalgae. - Journal of Phycology 35: 403-424. https://doi.org/10.1046/j.1529-8817.1999.3520403.x.

[18] Hubenov, Z., Kenderov, L., Pandourski, I. (2015): Invertebrate animals (Metazoa: Invertebrata) of the Atanasovsko Lake, Bulgaria. - Historia naturalis bulgarica 22: 45-71.

[19] Ivanov, K., Sotirov, A., Rozhdestvensky, A., Vodenicharov, D. (1964): The lakes of Bulgaria. - Proceedings of the Institute of Hydrology and Meteorology 16: 1-243. (In Bulgarian).

[20] Kennish, M. J., Paerl, H. W. (2010): Coastal lagoons: critical habitats of environmental change. - In: Kennish, M. J., Paerl, H. W. (eds.) Coastal Lagoons: Critical Habitats of Environmental Change. Boca Raton, CRC Press, pp. 1-15.

[21] Kennish, M. J. (2015): Coastal Lagoons. - In: Kennish, M. (ed.) Encyclopedia of Estuaries. Springer.

[22] Keresztes, Z. G., Felföldi, T., Somogyi, T., Székely, G., Dragoş, N., Márialigeti, K., Bartha, C., Vörös, L. (2012): First record of picophytoplankton diversity in Central European hypersaline lakes. - Extremophiles 16(5): 759-769. https://doi.org/10.1007/s00792-012-0472-x.

[23] Komárek, J., Fott, B. (1983): Chlorophyta (Grünalgen) Ordnung: Chlorococcales. - In: Huber-Pestalozzi, G. (ed.) Das Phytoplankton des Süßwassers: Systematik und Biology 7(1). E. Schweizerbart'sche Verlagsbuchhandlung (Nägele u. Obermiller), Stuttgart.

[24] Komárek, J., Anagnostidis, K. (1999): Cyanoprokaryota 1 Teil: Chroococcales. - In: Ettl, H., Gärtner, G., Heynig, H., Möllenhauer, D. (eds.) Süßwasserflora von Mitteleuropa 19(1). Gustav Fischer Verlag, Stuttgart.

[25] Komàrek, J., Anagnostidis, K. (2005): Cyanoprokaryota, 2: Oscillatoriales. - In: Ettl, H., Gärtner, G., Heynig, H., Möllenhauer, D. (eds.) Süßwasserflora von Mitteleuropa 19(2). Gustav Fischer Verlag, Stuttgart.

[26] Krienitz, L., Bock, C., Kotut, K., Luo, W. (2012): Picocystis salinarum (Chlorophyta) in saline lakes and hot springs of East Africa. - Phycologia 51: 22-32. https://doi.org/10.2216/11-28.1.

[27] Kumar, S., Stecher, G., Tamura, K. (2016): MEGA7: molecular evolutionary genetics analysis version 7.0 for bigger datasets. - Molecular Biology and Evolution 33: 18701874. https://doi.org/10.1093/molbev/msw054.

[28] Lewin, R. A., Krienitz, L., Goericke, R., Takeda, H., Hepperle, D. (2001): Picocystis salinarum gen. et sp. nov. (Chlorophyta) - a new picoplanktonic green alga. - Phycologia 39: 560-565. https://doi.org/10.2216/i0031-8884-39-6-560.1.

[29] Nei, M., Kumar, S. (2000): Molecular Evolution and Phylogenetic. - Oxford University Press, New York.

[30] OECD (1982): Eutrophication of Waters. Monitoring, assessment and control. - Final Report, OECD cooperative programme on monitoring of inland waters (Eutrophication control), Environment Directorate, OECD, Paris.

[31] Paranhos, R., Somogyi, B., Pálffy, K., Balogh, K., Botta-Dukát, Z., Vörös, L. (2017): Unusual behaviour of phototrophic picoplankton in turbid waters. - PLoS ONE 12(3): e0174316. https://doi.org/10.1371/journal.pone.0174316.

[32] Popovský, J., Pfiester, L. A. (2008): Dinophyceae. - Spectrum Akademischer Verlag, Heidelberg.

[33] R Core Team (2019): R: A language and environment for statistical computing. - Vienna, Austria. URL: https://www.R-project.org/.

[34] Reynolds, C. S. (2006): The ecology of phytoplankton. - Cambridge University Press, Cambridge.

[35] Schapira, M., Buscot, M., Pollet, T., Leterme, S., Seuront, L. (2010): Distribution of picophytoplankton communities from brackish to hypersaline waters in a South Australian coastal lagoon. - Saline Systems 6(1): 2. https://doi.org/10.1186/1746-1448-62. 
[36] Schlösser, U. (1982): Sammlung von Algenkulturen. - Berichte der Deutschen Botanischen Gesellschaft 95: 181-276. https://doi.org/10.1111/j.1438-8677.1982.tb02862.x.

[37] Somogyi, B., Felföldi, T., Vanyovszki, J., Ágyi, Á., Márialigeti, K., Vörös, L. (2009): Winter bloom of picoeukaryotes in Hungarian shallow turbid soda pans and the role of light and temperature. - Aquatic Ecology 43(3): 735-744. https://doi.org/10.1007/s10452009-9269-0.

[38] Somogyi, B., Felföldi, T., Solymosi, K., Makk, J., Nomonnay, Z. G., Horváth, G., Turcsi, E., Böddi, B., Márialigeti, K., Vörös, L. (2011): Chloroparva pannonica gen. et sp. nov. (Trebouxiophyceae, Chlorophyta) - a new picoplanktonic green alga from a turbid, shallow soda pan. - Phycologia 50: 1-10. https://doi.org/10.2216/10-08.1.

[39] Somogyi, B., Felföldi, T., Solymosi, K., Flieger, K., Márialigeti, K., Böddi, B., Vörös, L. (2013): One step closer to eliminating the nomenclatural problems of minute coccoid green algae: Pseudochloris wilhelmii, gen. et sp. nov. (Trebouxiophyceae, Chlorophyta). - European Journal of Phycology 48(4): 427-436. https://doi.org/10.1080/09670262.2013.854411.

[40] Somogyi, B., Vörös, L., Pálffy, K., Székely, G., Bartha, C., Keresztes, Z. (2014): Picophytoplankton predominance in hypersaline lakes (Transylvanian Basin, Romania). Extremophiles 18: 1075-1084. https://doi.org/10.1007/s00792-014-0685-2.

[41] Stasinopoulos, M. D., Rigby, R. A., Heller, G., Voudouris, V., Bastiani, F. (2017): Flexible Regression and Smoothing Using GAMLSS in R. $-1^{\text {st }}$ ed.: CRC Press.

[42] Utermöhl, H. (1958): Zur Vervollkommnung der quantitativen Phytoplankton-Methodik. - Schweizerbart, Stuttgart.

[43] Vadrucci, M. R., Stanca, E., Mazziotti, C., Umani, S. F., Georgia, A., Moncheva, S., Romano, A., Bucci, R., Ungaro, N., Basset, A. (2013): Ability of phytoplankton trait sensitivity to highlight anthropogenic pressures in Mediterranean lagoons: A size spectra sensitivity index (ISS-phyto). - Ecological Indicators 34: 113-125. http://dx.doi.org/10.1016/j.ecolind.2013.04.013.

[44] Wang, S., Lambert, W., Giang, S., Goericke, R., Palenik, B. (2014): Microalgal assemblages in a poikilohaline pond. - Journal of Phycology 50: 303-309. https://doi.org/10.1111/jpy.12158.

[45] Yamamoto, M., Nozaki, H., Miyazawa, Y., Koide, T., Kawano, S. (2003): Relationship between presence of a mother cell wall and speciation in the unicellular microalga Nannochloris (Chlorophyta). - Journal of Phycology 39: 172-184. https://doi.org/10.1046/j.1529-8817.2003.02052.x. 